\title{
New Yorker Gericht spricht zwei Schiele-Werke den Grünbaum-Erben zu
}

\author{
Supreme Court of the State of New York, County of New York: Commercial Division
}

Timothy Reif and David Fraenkel, as Co-Executors of the Estate of Leo Fisher and Milos Vavra (Plaintiffs and Counterclaim Defendants)

$$
\text { - against - }
$$

Richard Nagy, Richard Nagy Ltd., Artworks by the Artist Egon Schiele, known as "Woman in a Black Pinafore" and "Woman Hiding her Face" (Defendants and Counterclaim Plaintiffs)

Index No. 161799/2015 NYSCF Doc. No. 288 Received NYSEF: 04/04/2018 (redaktionell bearbeitet)

C.E. Ramos, J.S.C.: It is sad to note that this case, involving the determination of title to two works of art by the artist, Egon Schiele, is directly concerned with the most tragic event of our time, the Nazi Holocaust. The works are Woman in a Black Pinafore and Woman Hiding her Face (Artworks). In motion sequence numbers 008 and 009, each side has moved for summary judgement.

\section{Background}

The plaintiffs are Milos Vavra, and the co-heirs and co-executors of the estate of Leon Fisher, Timothy Reif and David Fraenkel. The District Court Innere Stadt Vienna has declared Messrs. Vavra and Fisher to be heirs of Franz Friedrich ("Fritz") Grunbaum (Dowd Aff., Ex. 1, September 12, 2002 Certificate of Heirship).

Mr. Grunbaum was a cabaret performer of Jewish Viennese descent living in Austria at the time of the Anschluss, and was a vocal critic of the Nazis. Mr. Grunbaum became a victim of Nazi persecution who was arrested in 1938 and murdered in the Dachau Concentration Camp in 1941 (Dowd Aff., Ex. 3, Fritz Grunbaum Death Certificate). Prior to this arrest, Mr. Grunbaum was a prolific art collector who owned hundreds of works of art, including many by Schiele.

A series of Nazi-era documents reveal the gut-wrenching process by which Mr. Grunbaum's property was looted. On April 26, 1938, the Nazis passed the "Decree Regarding the Reporting of Jewish Property", which required all Jews to declare property valued at or over 5000 Reichsmark. The goal was for the Nazis to seize the property to fund their war machine. As part of enforcing the decree, the Nazis coerced Mr. Grunbaum to execute a Power of Attorney to his wife, enabling her to complete Jewish Property Declarations on his behalf while he was at the concentration camp (Dowd Aff., Ex. 1, July 16, 1938 Power of Attorney; Ex. 1, 1938 and 1939 Jewish Property Declarations; Ex. 33, 1939 Statement of Property).
Franz Kieslinger, a Nazi official, appraised Mr. Grunbaum's property, revealing that it consisted of over 400 works of art, 81 of which were Schiele works (Dowd Aff., Ex. 1, April 27, 1938 Kieslinger Inventory). The completion of the looting was documented in 1939 Jewish Property Declarations, which were stamped "Erledigt" (completed) and "Gesperrt" (blocked), indicating that Mr. Grunbaum's property had been spoliated (Dowd Aff., Ex. 1, 1939 Jewish Property Declarations). The authenticity of these documents is undisputed.

The defendants, Richard Nagy and Richard Nagy Ltd., are currently in possession of the Artworks. Mr. Nagy is a professional art dealer, and director of Richard Nagy Ltd., a private company headquartered in London, England (Dowd Aff., Ex. 1, Annual Return of Richard Nagy Ltd.).Defendants assert that they have good title to the Artwork stemming from Mr. Grunbaum's sister-in-law, Mathilde Lukacs, who sold 54 works, including the Artworks, to a gallery in Switzerland. That gallery, called Gutekunst \& Klipstein (the Gallery), then owned by Eberhard Kornfeld, subsequently advertised the works in a catalogue for sale (Sale Catalogue) in 1956 (Dowd Aff., Ex. 6, 1956 Gutekunst \& Klipstein Catalogue).

Defendants owned a half share in Woman in a Black Pinafore from 2004 until 2011, when Mr. Nagy returned it due to provenance issues (Dowd Aff., Ex. 9, October 2011 Letter from Richard Nagy to Thomas Gibson Fine Art). Defendants re-purchased that half share (Dowd Aff., Ex. 10, December 9, 2013 Letter from Richard Nagy to Thomas Gibson Fine Art), as well as a full share in Woman Hiding her Face, in or after December of 2013 (Id.; Dowd Aff., Ex. 4, December 18, 2013 Art Sale and Transfer Agreement).

In an e-mail dated November 13, 2015, plaintiffs' attorney made a demand to defendants to return the Artworks to plaintiffs (Dowd Aff., Ex. 1, November 13, 2015 E-Mail from Raymand Dowd to Richard Nagy). The demand was refused, and this action followed. This Court has halted any sale of the Artworks pending resolution of the case.

In motion sequence numbers 007 and 008 , the parties have all moved for summary relief, each side contending that there are no triable issues of fact. In that regard, this Court agrees with them, but only one side can prevail.

\section{Discussion}

This dispute is governed by New York law. In Bakalar v Vavra, 619 F3d 136 [2d Cir 2010], a dispute relating to Nazi-looted art formerly belonging to Mr. Grunbaum, the Second Circuit rejected the Southern District's application of the law of the situs in favor of the interest analysis. The "law of the jurisdiction having the greatest Interest in the litigation is applied and the facts or 
contacts which obtain significance in defining State interests are those which relate to the purpose of the particular law in conflict" (Id., at 144) (citation and quotation marks omitted). In New York, a thief cannot pass good title, as New York refuses to become a marketplace for stolen artwork (Solomon R. Guggenheim Found. $v$ Lubell, 77 NY2d 311, 320 [1991]). New York's overwhelming interest in preserving the integrity of its market warrants the application of New York law (Bakalar v Vavra, 619 F3d, at 145).

A motion of summary judgment will be granted once a movant has made a prima facie showing of entitlement to judgment as a matter of law, and furnished sufficient evidence to eliminate any triable issues of material fact (Giuffrida $v$ Citibank Corp., 100 NY2d 72, 81 [2003]). Plaintiffs move for summary judgment on their claims for replevin and conversation.

An action for replevin requires the plaintiff to show legal title or a superior right of possession (In re Flamenbaum, 27 Misc3d 1090, 1096 [NY Sur Ct, Nassau Cty 2010], rev'd. 95 AD3d 1318 [1st Dept 2012], aff'd, 22 NY3d 962 [2013]). Relatedly, an action for conversion requires the plaintiff to prove that the property is in the unauthorized possession of another who acted to exclude the plaintiff's rights (Republic of Haiti v Duvalier, 211 AD2d 379, 384 [1st Dept 1995]).

This case must be viewed in context. In 2016, Congress passed the Holocaust Expropriated Art Recovery Act of 2016 (HEAR Act). The two purposes of the HEAR Act are:

(1) To ensure that laws governing claims to Nazi-confiscated art and other property further United States policy as set forth in the Washington Conference Principles on Nazi-Confiscated Art, the Holocaust Victims Redress Act, and the Terezin Declaration, and

(2) To ensure that claims to artwork and other property stolen or misappropriated by the Nazis [during the Holocaust] are not unfairly barred by statutes of limitations but are resolved in a just and fair matter.

(HEAR Act, Pub L No 114-308, at § 3 [2016]). In pursuit of theses aims, the HEAR Act extended the statute of limitations in which a claim may be brought to six years from the time that the artwork's identity and location, and the claimant's possessory interest, are discovered (Id., at § 5 [a]). Previously, CPLR § 214 [3] limited the timeliness of actions for the return of Nazi-looted art to three years from the time that the true owner demanded the return of the chattel, and the good faith purchaser refused to return it (Menzel $v$ List, 49 Misc2d 300, 304-5 [1966], modified, 28 AD2d 516 [1st Dept 1967], rev'd as to modific., 24 NY2d 91 [1969]). The HEAR Act applies to artworks that were looted between January 1, 1933 and December 31, 1945 (Id., at §4[4]).

Before Congress adopted the Washington Conference Principles on Nazi-Confiscated Art (Principles) in the HEAR Act, the Principles, dated December 3, 1998, were endorsed by 44 governments, including the United States, on December 3, 1998. Significantly, the Principles aim to assist in resolving issues surrounding Nazi-confiscated art:

In establishing that a work of art had been confiscated by the Nazis and not subsequently restituted, consideration should be given to unavoidable gaps or ambiguities in the provenance in light of the passage of time and the circumstances of the Holocaust era (Washington Conference Principles on Nazi-Confiscated Art, at १ 4 [1998]).

The HEAR Act also adopts the Holocaust Victims Redress Act of 1997, which provides:

All governments should undertake good faith efforts to facilitate the return of private and public property, such as works of art, to the rightful owners in cases where assets were confiscated from the claimant during the period of Nazi rule and there is reasonable proof that the claimant is the rightful owner (Holocaust Victims Redress Act, Pub L No 105-158, Title II, at § 202 [1997]).

The HEAR Act compels us to help return Nazi-looted art to its heirs (HR Rep Vol 162, No 176, at H7332 [Dec. 7, 2016]) ("This legislation will help restore artwork and heritage stolen by the Nazis during the Holocaust to the rightful owners or heirs."). As this Court has previously explained,

The enactment was based on a Congressional finding that victims of Nazi persecution and their heirs have faced significant procedural obstacles, due in part to State statutes of limitation, to lawsuits brought in the United States to recover misappropriated artworks and other property, and that relief is necessary due to the unique and horrific circumstances of the Holocaust and the difficulty of documenting claims (Estate of Kainer v UBS AG, No. 650026/2013, 2017 NY Misc Lexis 4153, at *43-44 [NY Sup Ct, Oct 30, 2017]).

The act was only made into law in 2016. To the extent that defendants rely on judicial findings relating to claims ort defences articulated in Bakalar v Vavra, 819 FSupp2d 293 [SDNY 2011] (Bakalar), such discussion is irrelevant.

There is no triable issue of fact as to whether the Artworks belonged to Mr. Grunbaum before World War II. Although defendants attempt to dispute this, even the Gallery on which defendants rely as the source of their provenance has confirmed that Mr. Grunbaum had owned the works. An e-mail sent from Mr. Kornfeld's namesake gallery, Galerie Kornfeld, to Dover Street Gallery in 2004 states that all Schieles from the Sale Catalogue had the same provenance stemming from Mr. Grunbaum:

- Collection Fritz Grunbaum

- Elisabeth Grunbaum-Herzl (widow)

- Mathilde Lukacs-Herzl (sister of Elisabeth) 
(Dowd Aff., 26, September 23, 2004 E-mail from Wolf von Weiler to Dover Street Gallery). Defendants' Answer with Counterclaims (Answer) also states that the Artworks have the "identical provenance" of the drawing that the Southern District found to have been owned by Fritz Grunbaum is Bakalar (Dowd Aff., Ex. 2, Answer, at 9 2). Defendants repeatedly refer to this decision in their Answer, as well as their failed collateral estoppel motion (Mot. Seq. No. 003). Defendants therefore cannot simultaneously argue that Mr. Grunbaum never owned the Artworks.

In the HEAR Act, the Principles, and the Holocaust Victims Redress Act, we are instructed to be mindful of the difficulty of tracing artwork provenance due to the atrocities of the Holocaust era, and to facilitate the return of property where there is reasonable proof that the rightful owner is before us (Holocaust Victims Redress Act, Title II, at § 202). We accept that the Artworks were the property of Mr. Grunbaum, and that the entirety of Mr. Grunbaum's property was looted by the Nazis during World War II. As the heirs of Mr. Grunbaum, plaintiffs have made a threshold showing that they have an arguable claim of a superior right of possession to the Artworks, and that the Artworks are in the unauthorized possession of another who is acting to exclude plaintiffs' rights. Plaintiffs have therefore established to this Court's satisfaction that they have a prima facie case of both replevin and conversion.

Confronted with plaintiffs' prima facie case, the burden of proof shifts to defendants to establish they have a superior claim to the Artworks, or to at least raise a triable issue of fact (Zuckerman v City of New York, 49 NY2d 557 [1980]). This they are unable to do. "The burden of proving that the painting was not stolen property rests with [the possessor]" (Solomon R. Guggenheim Found. v Lubell, NY2d, at 321). "[M]ere conclusions, expressions of hope or unsubstantiated allegations or assertions are insufficient" (Zuckerman v City of New York, 49 NY2d, at 562).

Defendants have neither presented evidence nor raised a triable issue of fact to show that Mr. Grunbaum voluntarily transferred the subject artworks during his lifetime. Although the Nazis confiscated Mr. Grunbaum's artworks by forcing him to sign a power of attorney to his wife, who was herself later murdered by the Nazis, the act was involuntary (Menzel $v$ List, 49 Misc 2d 300, at 305) ("The relinquishment here by the Menzels in order to flee from their lives was no more voluntary than the relinquishment of property during a holdup ... The court finds, accordingly, as a matter of law, that there was no abandonment.") A signature at gunpoint cannot lead to a valid conveyance.

New York protects the rightful owner's property where that property had been stolen, even if the property is in the possession of a good faith purchaser for value (Solomon R. Guggenheim Found. $v$ Lubell, 77 NY2d, at 317). A thief cannot convey good title (Id.). While defendants argue that they purchased the Artworks in good faith, title remains with the original owner or his heirs absent a valid conveyance of the works $(I d$.). As defendants have not shown that Mr. Grunbaum ever voluntarily transferred the Artworks to Ms. Lukacs, they cannot credibly allege that she owned them (Gruen v Gruen, 68 NY2d 48, 53 [1986]).

Moreover, any evidence to suggest that Ms. Lukacs possessed good title to the Artworks is absent from the record. Mr. Kornfeld's deposition testimony in Bakalar reveals that he, an experienced art dealer, apparently did not request Ms. Lukacs to provide identification and confirm provenance when he purchased the Artworks from her (Jamberdino Aff., Ex. I, Expert Report of Laurie A. Stein, at 38-39). He also failed to list her name in the Sale Catalogue to show the provenance of the Artworks. In addition, his testimony is inconsistent as to how he found out that the works in the Sale Catalogue once belonged to Mr. Grunbaum.

In a single deposition, Mr. Kornfeld testified that he did not learn about Mr. Grunbaum until the late 1990s, and that he had never heard of Mr. Grunbaum (Dowd Aff., Ex. 19, Declaration and Expert Report of Jonathan Petropoulos, at 24). Neither of these statements appears to be true, as the 1956 Sale Catalogue listed the provenance for the painting Dead City III as stemming from Mr. Grunbaum (Id.). Mr. Kornfeld also testified that all works in the Sale Catalogue had the same provenance (Id.). Interestingly, German and Swiss governmental reports have listed Mr. Kornfeld as someone who trafficked in Nazi-looted art (Id., at 26). Defendants have not disputed any of these facts, and have failed to meet their burden of showing that the Artworks were not stolen, or that there is a question of fact necessitating trial.

Defendants' Answer presented 18 defenses: (1) collateral estoppel based on Bakalar, (2) failure to state a claim, (3) laches, (4) defendants' good faith acquisition, (5) lack of standing based on Bakalar, (6) lack of subject matter and personal jurisdiction, (7) international comity, (8) statute of limitations, (9) applicability of the foreign law of Austria, Switzerland and the United Kingdom, (10) adverse possession, (11) lack of prejudice to plaintiffs by any of defendants' alleged actions, (12) failure to exhaust remedies, (13) lack of injuries, (14) waiver, (15) failure to join necessary parties, (16) injuries were caused by third parties, (17) dereliction and abandonment, (18) the future right to assert additional defenses.

The defenses are grouped and analyzed below.

The 3rd and 8th defenses relate to the timeliness of plaintiffs' complaint. Plaintiffs discovered the Artworks at Mr. Nagy's booth at the Salon Art + Design Show at the Park Avenue Armory in New York City in November of 2015. Plaintiffs' attorney subsequently made a demand for defendants to return the property on November 13, 2015, which was refused (Dowd Aff., Ex. 1, November 13, 2015 E-mail from Raymond Dowd to Richard Nagy). Seeing the plaintiffs filed the present action in 2015, the action is timely under the three-year statute of limitations in CPLR § 214 [3] (Solomon R. Guggenheim Found. v Lubell, 77 NY2d, at 317-18). 
Moreover the HEAR Act expanded the timeliness for actions to recover Nazi-looted artwork to six years from "the actual discovery by the claimant" of the "identity and location of the artwork" and of "possessory interest of claimant in the artwork" (HEAR Act, $§ 5[a])$. Congress has also instructed that actions brought within six years will be timely, "[n]otwithstanding ... any defense at law relating to the passage of time" (Id.). Although defendants argue that the HEAR Act is inapplicable, this argument is absurd, as the act is intended to apply to cases precisely like this one, where Nazi-looted art is at issue. Since plaintiffs discovered the Artworks in November of 2015, their action is timely under the HEAR Act (Maestracci v Helly Nahmad Gallery, Inc., 155 AD3d 401, 404-5 [1st Dept 2017]). The statute of limitations and laches defenses fail.

Defendants' laundry list of other defenses are also unsuccessful, as briefly discussed below. The 1st and 5th defenses of collateral estoppel and lack of standing based on Bakalar are improper. As already noted, the Southern District's decision in Bakalar was issued before Congress enacted the HEAR Act, and its reasoning is inapplicable to this case. We have also already denied defendants' collateral estoppel motion. The 2 nd defense of failure to state a claim does not apply, as plaintiffs have stated a prima facie case. The 4th defense that defendants acquired the Artworks in good faith is inapplicable, because a thief cannot convey good title (Menzel $v$ List, 49 Misc $2 d$ 300, at 315). The 7th and 9th defenses relating to international comity and the applicability of foreign law are irrelevant, as we have already stated that New York law applies under the interest anaIysis (Solomon R. Guggenheim Found. V Lubell, 77 NY2d, at 320). The remaining 6th, and 10th through 18th defenses are conclusory and were not adequately pleaded (Kronish Lieb Weiner \& Hellman LLP v Tahari, Ltd., 35 AD3d 317, 319 [1st Dept 2006]). Bare legal conclusions are insufficient to raise an affirmative defense (Robbins v Growney, 229 AD2d 356, 358 [1st Dept 1996]).

It is worth noting that questions regarding the validity of title have affected the market value of the Artworks. Mr. Nagy is a Schiele expert. In 1998, the art world was put on notice of potential provenance issues with Schiele artworks when the New York County District Attorney issued a subpoena to the Museum of Modern Art to seize two Schiele works, even though the Court of Appeals ultimately held that the works could not be subject to seizure because they were on exhibit from abroad (People v Museum of Modern Art (In re Grand Jury Subpoena Duces Tecum), 93 NY2d 729 [1999]). In or around June or July 2004, defendants paid 91140.00 British Pounds $(£)$ for a half share of Woman in a Black Pinafore (Dowd Aff., Ex. 39, June 23, 2004 Invoice from Thomas Gibson Fine Art to Richard Nagy), a steep discount from the amount between $£ 350000$ and $£ 450000$ that Sotheby's estimated it would sell for the day prior.

The Art Loss Register and plaintiffs' attorney, Raymond Dowd, wrote to Mr. Nagy on numerous occasions in 2004 and 2005, informing Mr. Nagy that Mr. Grunbaum's heirs were searching for works that belonged to his estate (Dowd Aff., Ex.
7, June 8, 2005 Letter from Sarah Jackson to Richard Nagy; Ex. 23, August 10, 2004 Faxed Letter from Antonia Kimbell to Julia Theill; Ex. 24, September 8, 2004 Letter from Antonia Kimbell to Julia Theill; Ex. 27, September 27, 2004 Faxed Letter from Sarah Jackson to Caroline Schmidt; Ex. 28, October 11, 2005 Letter from Raymond Dowd to Richard Nagy). Mr. Nagy even returned his half share of Woman in a Black Pinafore in 2011 due to provenance issues (Dowd Aff., Ex. 9, October 21, 2011 Letter from Richard Nagy to Thomas Gibson Fine Art), before buying it back in 2013 following the decision in Bakalar (Dowd Aff., Ex. 8, February 24, 2005 Letter from Thomas Gibson Fine Art to Richard Nagy; Ex. 10, December 9, 2013 Letter from Richard Nagy to Thomas Gibson Fine Art). To his credit, evidence indicates that Mr. Nagy inquired regarding the provenance of Woman in a Black Pinafore with Sotheby's (Dowd Aff., Ex. 25, September 28, 2004 E-mail Chain Sent from Caroline Schmidt to Thomas Gibson), and the Art Loss Register before it was shipped to him, though the findings were not conclusive (Dowd Aff., Ex. 23, August 10, 2004 Faxed Letter from Antonia Kimbell to Julia Theill; Ex. 24, September 8, 2004 Letter from Antonia Kimbell to Julia Theill; Ex. 27, September 27, 2004 Faxed Letter from Sarah Jackson to Caroline Schmidt; Ex. 29, August 10, 2004 Letter from Antonia Kimbell to Richard Nagy).

On December 18, 2013, Mr. Nagy purchased Woman Hiding her Face for $\$ 1.5$ million from the Estate of Doris Rubin, six years after her death (Dowd Aff., Ex. 4, December 18, 2013 Art Sale and Transfer Agreement). Potential ownership claims by Grunbaum heirs were acknowledged in the Art Sale and Transfer Agreement, which required the seller to obtain a title insurance policy (Id., at $\uparrow 10)$. That same day, Mr. Nagy entered into a resale agreement with Michael Goddard of Baltic Partners Limited in the Cayman Islands (Dowd Aff., Ex. 11, December 18, 2013 Letter from Baltic Partners Limited to Richard Nagy). Mr. Goddard agreed to pay \$1.5 million to Mr. Nagy, and in return Mr. Nagy acquired exclusive rights to remarket the work for no less than $\$$ 2.5 million, insured on an all risk basis (Id.). These facts show that Mr. Nagy did not pay full value for Woman Hiding her Face, and that defendants were aware of the Artworks' Nazi provenance and plaintiffs' claims.

As plaintiffs have succeeded in this action, we must deny defendants' motion for summary judgment on their counterclaims for declaratory judgment and slander of title.

\section{Accordingly, it is herby}

ORDERED that plaintiffs' motion for summary judgment on replevin and conversion claims is granted. The parties are directed to settle an order on notice vesting title in Mr. Grunbaum's estate, and denying defendants' motion. 